\title{
A STUDY OF PALLOR IN ELDERLY- HAEMATOLOGICAL PROFILE
}

\author{
Sonaline Suzatte Fernandez ${ }^{1}$, Prabhalakshmi K. K², Sankar $S^{3}$
}

1 Resident, Department of Pathology, Government Medical College, Kottayam.

${ }^{2}$ Associate Professor, Department of Pathology, Government Medical College, Kottayam.

3 Professor and HOD, Department of Pathology, Government Medical College, Kottayam.

ABSTRACT
BACKGROUND
Anaemia in the elderly (age $>65$ years) is defined as a haemoglobin concentration below 12
men respectively. This decrease in oxygen carrying capacity can lead to overall decline in
hospitalisation at higher rates than those without anaemia. In elderly population anaemia is
changes, which is not a correct approach as anaemia can never be a normal physiological ph
problem, this study was undertaken on patients attending a tertiary care hospital.
The objectives of the study are-
1. To study the clinical profile of elderly patients with anaemia.
2. To study the haematological characteristics to know the patterns of anaemia in elderly.

\section{MATERIALS AND METHODS}

A descriptive study was conducted to study the clinical profile and the haematological characteristics to know the patterns of anaemia in elderly patients approaching Department of Medicine, Govt. Medical College, Kottayam during a period of 12 months (May 2015 - May 2016). Statistical analysis was done with available software.

\section{RESULTS}

Among the 350 patients examined, easy fatigability was the presenting symptom of most of the patients. The patients had varied physical examination findings corresponding to their underlying disease. Haematological profile showed that most of the patients had Grade 1 anaemia and normocytic normochromic blood picture on peripheral smear examination.

\section{CONCLUSION}

Normocytic normochromic anaemia is the most common pattern on peripheral blood smear of elderly anaemic patients. The findings are comparable to other Indian studies on this subject.

\section{KEYWORDS}

Anaemia; Elderly; Clinical Profile; Haematology Approach.

HOW TO CITE THIS ARTICLE: Fernandez SS, Prabhalakshmi KK, Sankar S. A study of pallor in elderly- haematological profile. J. Evolution Med. Dent. Sci. 2017;6(92):6630-6638, DOI: 10.14260/jemds/2017/1437

\section{BACKGROUND}

In the geriatric age group, usually patients present with common symptoms like fatigue, weakness and shortness of breath; that is why in geriatric age group anaemia is usually ignored by the physicians, confirming the patterns of anaemia is critical to direct the investigation for profiling the aetiology since it is well known that the treatment of anaemia goes a long way in improving the overall outcome and quality of life. Failure to evaluate anaemia in elderly could lead to delayed diagnosis of potentially treatable conditions. ${ }^{1}$

However, there are at least two reasons for considering anaemia in the elderly as a sign of disease. First, most of the older people maintain a normal red cell count, haemoglobin and haematocrit. Second, in most elderly patients an underlying cause of anaemia is found for haemoglobin of less

'Financial or Other Competing Interest': None.

Submission 12-10-2017, Peer Review 18-11-2017,

Acceptance 23-11-2017, Published 04-12-2017.

Corresponding Author:

Dr. Prabhalakshmi K. K

Department of Pathology,

Government Medical College,

Kottayam.

E-mail: prabha3463@gmail.com

DOI: $10.14260 /$ jemds $/ 2017 / 1437$

\section{(c) (i) $(\Theta$}

than $12 \mathrm{~g}$ per dL. Dr. Artz stated that in elderly persons, the aetiology of anaemia differs sufficiently from younger adults to warrant considering anaemia in elderly person as a distinct entity. So, aetiological diagnosis of anaemia is essential for prompt and effective treatment of elderly anaemic patients in order to prevent disability. ${ }^{2}$

\section{Relevance of History Taking in Assessing Anaemia in Elderly}

Carefully obtaining a history and performing a physical examination in every patient with anaemia is important, because the findings usually provide important clues to the underlying disorder. From the standpoint of the investigation of the anaemia, asking questions in addition to those conventionally explored during a routine examination is important. Areas of inquiry are found valuable and are briefly described below.

Often, the duration of anaemia can be established by obtaining a history of previous blood studies and if necessary by acquiring those records. Similarly, a history of rejection as a blood donor or prior prescription of haematinics provides clues that anaemia was detected previously.

It is better to obtain a careful family history not only for anaemia but also for jaundice, cholelithiasis, splenectomy, bleeding disorders and abnormal haemoglobins. Carefully document the patient's occupation, hobbies, prior medical 
treatment, drugs (including over-the-counter medications and vitamins) and household exposures to potentially noxious agents. Patients are unlikely to volunteer exposures to tranquilisers, insecticides, paints, solvents and hair dyes unless specifically queried.

Often, patients do not appreciate the significance of tarry stools. Changes in bowel habits can be useful in uncovering neoplasms of the colon. Haemorrhoidal blood loss is difficult to quantify, and it may be overlooked or overestimated from one patient to another. Obviously, seek a careful history of gastrointestinal complaints that may suggest gastritis, peptic ulcers, hiatal hernias or diverticula. Abnormal urine colour can occur in renal and hepatic disease and in haemolytic anaemia.

A thorough dietary history is important in a patient who is anaemic. This history must include food habits like foods that the patient eats and those that he/she avoids as well as an estimate of their quantity. A meal-by-meal description is necessary to obtain appropriate estimates. Even then, patients frequently attempt to deceive the physician because of embarrassment regarding dietary idiosyncrasies or financial restrictions. In these circumstances having a close and concerned family member participate in the dietary history can often be helpful, because this person is usually more objective than the patient.

Specifically question patients regarding consumption of either clay or laundry starch. This history will not be provided spontaneously. These substances render iron less absorbable. Changes in body weight are important with regard to dietary intake and can suggest the presence of malabsorption.

Nutritional deficiencies may be associated with unusual symptoms that can be elicited by a history. Patients with iron deficiencies frequently chew or suck ice (pagophagia). Occasionally, they complain of dysphagia, brittle fingernails, relative impotence, fatigue and cramps in the calves on climbing stairs that are out of proportion to their anaemia.

In vitamin B12 deficiency early greying of the hair, a burning sensation in the tongue and a loss of proprioception are common. Suspect a loss of proprioception if the patient stumbles in the dark or must look in order to put on pants in the morning. Paraesthesia or unusual sensations frequently described as pain also occur in pernicious anaemia.

Patients with folate deficiency may have a sore tongue, cheilosis and symptoms associated with steatorrhea. Colour, bulk, frequency and odour of stools and whether the faeces float or sink can be helpful in detecting malabsorption. More sensitive questions to detect steatorrhea include whether the toilet needs to be flushed more than once to rid it of stool and whether an oily substance is floating on the water surface after the first flush.

Obtain a history of fever or identify the presence of fever, because infections, neoplasms and collagen vascular disease can cause anaemia. Similarly, the occurrence of purpura, ecchymoses and petechiae suggest the occurrence of either thrombocytopenia or other bleeding disorders. This may be an indication either that more than 1 bone marrow lineage is involved or that coagulopathy is a cause of the anaemia because of bleeding.

Cold intolerance can be an important symptom of hypothyroidism or lupus erythematosus, paroxysmal cold haemoglobinuria and certain macroglobulinaemias. The relation of dark urine to either physical activity or time of day can be important in march haemoglobinuria and paroxysmal nocturnal haemoglobinuria. Explore the presence or the absence of symptoms suggesting an underlying disease such as cardiac, hepatic and renal disease, chronic infection, endocrinopathy or malignancy. A geographic history can also be important in establishing an aetiology.

Symptoms and Signs to be assessed in Anaemia in Elderly Especially when mild and insidious in onset, anaemia often causes no symptoms. When they occur, fatigue and listlessness are common. As the anaemia worsens, dyspnoea may occur because of the diminished oxygen supplied to the tissues or from high-output cardiac failure, which usually occurs only when the haematocrit drops below 20 , unless the patient has underlying heart disease. In patients with coronary artery disease, angina may develop or worsen. When the anaemia becomes severe, faintness, dizziness and diminished concentration can occur from decreased oxygen delivery to the brain. Diminished tissue oxygenation may provoke the compensatory mechanisms of tachycardia and increased force of ventricular contraction, which patients sometimes detect as palpitations.

The symptoms of anaemia vary according to the type of anaemia, the underlying cause, the severity and any underlying health problems such as haemorrhage, ulcers, menstrual problems or cancer. Specific symptoms of those problems may be noticed first. The body also has a remarkable ability to compensate for early anaemia. If the anaemia is mild or has developed over a long period of time, there will be no symptoms.

\section{Symptoms Common to Many Types of Anaemia include the following-}

- Easy fatigue and loss of energy.

- Unusually rapid heartbeat, particularly with exercise.

- Shortness of breath and headache, particularly with exercise.

- Difficulty concentrating.

- Dizziness.

- Pale skin.

- Leg cramps.

- Insomnia.

- Other symptoms are associated with specific forms of anaemia.

\section{Anaemia caused by Iron Deficiency}

People with an iron deficiency may experience these symptoms: A hunger for strange substances such as paper, ice or dirt (a condition called pica), upward curvature of the nails, referred to as koilonychias, soreness of the mouth with cracks at the corners.

\section{Anaemia Caused by Vitamin B12 Deficiency}

People whose anaemia is caused by a deficiency of Vitamin B12 may have these symptoms: A tingling, "pins and needles" sensation in the hands or feet, lost sense of touch, a wobbly gait and difficulty walking, clumsiness and stiffness of the arms and legs and dementia. 


\section{Anaemia Caused by Chronic Lead Poisoning}

Chronic lead poisoning may lead to these symptoms: A blueblack line on the gums referred to as a lead line, abdominal pain, constipation and vomiting.

\section{Anaemia caused by Chronic Red Blood Cell Destruction}

Anaemia caused by chronic red blood cell destruction may include these symptoms: Jaundice (yellow skin and eyes), brown or red urine, leg ulcers and symptoms of gallstones.

\section{Anaemia caused by sudden Red Blood Cell Destruction} Abdominal pain, brown or red urine, jaundice (yellow skin), small bruises under the skin, seizures and symptoms of kidney failure.

\section{Anaemia caused by Underlying Haematological Malignancy}

Petechiae, ecchymosis, lymphadenopathy and hepatosplenomegaly.

Physical Examination to be carried out with Special Reference to Anaemia in Elderly

Too often the physician rushes into the physical examination without looking at the patient for an unusual habitus or appearance of underdevelopment, malnutrition or chronic illness. These findings can be important clues to the underlying aetiology of disease and provide information related to the duration of illness. The skin and mucous membranes are often bypassed so that pallor, abnormal pigmentation, icterus, spider nevi, petechiae, purpura, angiomas, ulcerations, palmar erythema, coarseness of hair, puffiness of the face, thinning of the lateral aspects of the eyebrows, nail defects and a prominent venous pattern on the abdominal wall are missed in the rush to examine the heart and the lungs.

Examine optic fundi carefully, but not at the expense of the conjunctivae and the sclerae which can show pallor, icterus, splinter haemorrhages, petechiae, comma signs in the conjunctival vessels or telangiectasia that can be helpful in planning additional studies.

Perform systematic examination for palpable enlargement of lymph nodes for evidence of infection or neoplasia. Bilateral oedema is useful in disclosing underlying cardiac, renal or hepatic disease, whereas unilateral oedema may portend lymphatic obstruction due to a malignancy that cannot be observed or palpated.

Carefully search for hepatomegaly and splenomegaly. Their presence or absence is important, as are the size, the tenderness, the firmness and the presence or the absence of nodules. In patients with chronic disorders these organs are firm, non-tender and non-nodular. In patients with carcinoma, they may be hard and nodular. The patient with an acute infection usually has a palpably softer and more tender organ.

A rectal and pelvic examination cannot be neglected, because tumour or infection of these organs can be the cause of anaemia.

The neurologic examination should include tests of position sense and vibratory sense, examination of the cranial nerves and testing for tendon reflexes. The heart should not be ignored, because enlargement may provide evidence of the duration and the severity of the anaemia and murmurs may be the first evidence of a bacterial endocarditis that could explain the aetiology of the anaemia.

\section{Laboratory Assessment of Anaemia}

Many cases of anaemia will be found during routine blood tests done for other reasons. The initial laboratory evaluation of anaemia will be determined by the patient's medical history and physical examination. When completed, the laboratory evaluation should include-

- Complete blood count (CBC).

- Iron profile.

- Vitamin profile.

- Erythropoietin level.

- Stool for occult blood.

\section{Complete Blood Count}

The CBC is important for the diagnosis of anaemia and for monitoring disease progression and treatment efficacy. When assessing the elderly anaemia patient, the most important components of the $\mathrm{CBC}$ are 83.

Erythrocyte (RBC) count: Reports the total number of RBCs per litre of whole blood.

- Normal range for men: 4.7 - 6.1 million cells/ mcL.

- Normal range for women: 4.2 - 5.4 million cells/ mcL.

$\mathrm{Hb}$ : Measures the amount of haemoglobin present in the blood. Dehydration may produce a falsely high $\mathrm{Hb}$.

- Normal range for men: $13-17 \mathrm{~g} / \mathrm{dL}$.

- Normal range for women: $12-16 \mathrm{~g} / \mathrm{dL}$.

Haematocrit (HCT): Packed cell volume in proportion to blood volume.

- Normal range for men: $40 \%$ to $52 \%$.

- Normal range for women: $36 \%$ to $48 \%$.

Mean cell (corpuscular) volume (MCV): Measures the average size of RBCs, a diagnostic parameter for evaluating anaemia, and differentiates microcytic and normocytic anaemia in the elderly.

- Normal range: 81 - $100 \mathrm{fL}$.

- Macrocytosis: Greater than $100 \mathrm{fL}$ with large RBCs.

Microcytosis: Less than $81 \mathrm{fL}$ with small RBCs.

Mean cell haemoglobin (MCH): Average amount of $\mathrm{Hb}$ in an RBC

- Normal range: 27 - $34 \mathrm{Hb} /$ cell.

Mean cell haemoglobin concentration (MCHC): Average concentration of $\mathrm{Hb}$ in an $\mathrm{RBC}$.

- Normal range: $30 \%$ to $36 \%$

RBC distribution width (RDW-CV): Measures variations in the size of RBCs.

- Normal range: $12 \%$ to $14 \%$

Leukocyte (white blood cell) Count: Reports the number of leukocytes in the blood; the differential includes different types of leukocytes (i.e. neutrophil, eosinophil, basophil, lymphocyte, monocyte).

- Normal range: $4,500-10,000$ cells/mcL 
Thrombocytes/ platelet count: Number of platelets present.

- Normal range: 150,000 - 450,000 cells/mcL

Clinicians should remember that laboratory values are not treated, patients are. Any abnormal laboratory results should be correlated with the physical condition of the patient and the patient's goals. Furthermore, different laboratories may use different reference values.

Symptoms of anaemia may occur when the $\mathrm{Hb}$ falls below $11 \mathrm{~g} / \mathrm{dL}$; when $\mathrm{Hb}$ falls below $8 \mathrm{~g} / \mathrm{dL}$ the anaemia is lifethreatening. The CBC provides valuable insight into the type of anaemia. If leucopenia and thrombocytopenia are present along with anaemia, a myelodysplastic disorder is suspected. The MCV reveals the size of the cells, leading to the classification of normocytosis, microcytosis or macrocytosis and indicating potential causes.

\begin{tabular}{|c|c|c|}
\hline Category & $\begin{array}{l}\text { Mean Corpuscular } \\
\text { Volume }\end{array}$ & $\begin{array}{l}\text { Possible causes of } \\
\text { Anaemia }\end{array}$ \\
\hline Microcytosis & $\begin{array}{l}<81 \mathrm{fL} \text { with small red } \\
\text { blood cells }\end{array}$ & $\begin{array}{c}\text { Iron deficiency, } \\
\text { Gastrointestinal } \\
\text { bleeding, } \\
\text { Thalassaemia, } \\
\text { Anaemia of chronic } \\
\text { inflammation }\end{array}$ \\
\hline Normal Range & $81-100 \mathrm{fL}$ & $\begin{array}{l}\text { Iron deficiency, } \\
\text { Gastrointestinal } \\
\text { bleeding, } \\
\text { Thalassaemia, } \\
\text { Anaemia of chronic } \\
\text { inflammation }\end{array}$ \\
\hline Macrocytosis & $\begin{array}{l}>100 \text { fL with large red } \\
\text { blood cells }\end{array}$ & $\begin{array}{c}\text { B12/ folate } \\
\text { deficiency, } \\
\text { drug effect, } \\
\text { Alcohol abuse, } \\
\text { Myelodysplasia, } \\
\text { Liver or thyroid } \\
\text { disease }\end{array}$ \\
\hline \multicolumn{3}{|c|}{$\begin{array}{c}\text { Categories of Mean Corpuscular Volume and Associated } \\
\text { causes of Anaemia }\end{array}$} \\
\hline
\end{tabular}

\section{Peripheral Smear Examination}

In patients with anaemia, physician-initiated examinations of blood smears are usually performed in response to clinical features or to a previously abnormal complete blood count. The presence of unexplained jaundice, particularly if unconjugated hyperbilirubinaemia is also present, is an additional reason for a blood smear examination. There are morphologic abnormalities that are critical in the differential diagnosis of anaemia and that can be determined only from a blood smear. Particularly important is the detection of variations in cell shape and of red cell inclusions, such as Howell-Jolly bodies (nuclear fragments), Pappenheimer bodies (hemosiderin-containing granules) and basophilic stippling or punctate basophilia (altered ribosomes).

\section{Clinical Indications for Examination of a Blood Smear}

Features suggestive of anaemia, unexplained jaundice or both. Features suggestive of sickle cell disease- dactylitis or sudden splenic enlargement and pallor in a young child or in an older child or adult, limb, abdominal or chest pain.
Features suggestive of thrombocytopenia (e.g. petechiae or abnormal bruising) or neutropenia (e.g. unexpected or severe infection).

Features suggestive of a lymphoma or other lymphoproliferative disorder- lymphadenopathy, splenomegaly, enlargement of the thymus (a mediastinal mass on radiology) or other lymphoid organs, skin lesions suggestive of infiltration, bone pain and systemic symptoms such as fever, sweating, itching and weight loss.

Features suggestive of a myeloproliferative diseasesplenomegaly, plethora, itching or weight loss. Suspicion of disseminated intravascular coagulation. Acute or recent onset renal failure or unexplained renal enlargement.

On retinal examination haemorrhages, exudates, signs of hyperviscosity or optic atrophy. Suspicion of a bacterial or parasitic disease that can be diagnosed from a blood smear.

Features suggestive of disseminated non-haematopoietic cancer, weight loss, malaise or bone pain.

General ill health, often with malaise and fever, suggesting infectious mononucleosis or other viral infection or inflammatory or malignant disease.

\section{Haemolytic Anaemia}

In the haemolytic anaemias, red cell shape is of considerable diagnostic importance. Some types of haemolytic anaemia yield such a distinctive blood smear that the smear is often sufficient for diagnosis. This is true of hereditary elliptocytosis, hereditary pyropoikilocytosis and Southeast Asian ovalocytosis, a distinctive type of inherited haemolytic anaemia that is common in some parts of Southeast Asia. Clinical features together with the results of a direct antiglobulin test, in patients with spherocytes will generally indicate the correct diagnosis. Microspherocytes (i.e. cells that are both hyperchromic and significantly reduced in size and therefore in diameter) may be present in low numbers in patients with a spherocytic haemolytic anaemia, but are also characteristic of burns and of microangiopathic haemolytic anaemia. The detection of a microangiopathic haemolytic anaemia is of considerable clinical significance, since this type of anaemia may indicate disseminated cancer, chronic disseminated intravascular coagulation, the haemolyticuraemic syndrome or thrombotic thrombocytopenic purpura; the latter two conditions both require urgent diagnosis so that appropriate management can be initiated. In microangiopathic haemolytic anaemia, examination of the blood smear is also important to validate the platelet count, since red cell fragments will measure same as platelets.

A blood smear is particularly important in the diagnosis of acute haemolysis induced by oxidant damage. The characteristic feature is the presence of keratocytes or "bite" cells, "blister" cells and irregularly contracted cells. G6PD deficiency affects millions of persons worldwide. A blood smear is important for the diagnosis of this condition for two reasons. First, it is available far more rapidly than are the results of a G6PD assay and when considered together with the patient's ethnic origin and clinical history permits a provisional diagnosis. Second, a blood smear can suggest the diagnosis of G6PD deficiency even if a G6PD assay is normal.

\section{Macrocytic Anaemia}

The blood smear is of great importance in the differential diagnosis of macrocytic anaemias. For patients in whom there 
is a deficiency of vitamin B12 or folic acid, the blood smear shows not only macrocytes but also oval macrocytes and hypersegmented neutrophils. When the anaemia is more severe, there may be marked poikilocytosis with teardrop poikilocytes and red cell fragments. Although, these deficiency states are now usually recognised on the basis of assays of vitamin B12 and folic acid, the blood smear remains important for two reasons. First, it permits a speedy provisional diagnosis and initiation of appropriate treatment in severely anaemic patients, while assay results are pending. Second, occasionally there are patients with a clinically significant vitamin B12 deficiency despite a normal assay result. This discrepancy occurs because much of the vitamin B12 that is measured in the assay is bound to haptocorrin, whereas the functional vitamin B12 which is bound to transcobalamin contributes much less to the assay of total B12.

Similarly, acute folic acid deficiency sometimes develops in patients even though the total red cell folate level remains normal. The observation of a blood smear that is typical of megaloblastic anaemia despite normal assays is an indication that further investigation and a trial of treatment are needed.

Liver disease and excess ethanol consumption are common causes of macrocytosis with the blood smear usually showing round rather than oval macrocytes and lacking hypersegmented neutrophils; target cells and stomatocytes may also be present.

In elderly patients, the myelodysplastic syndromes are an important cause of macrocytosis. Blood smear features that may point to the diagnosis include hypogranular or hypolobulated neutrophils, blast cells, giant or hypogranular platelets, Pappenheimer bodies and the presence of a minor population of hypochromic microcytic cells leading to a dimorphic smear. When macrocytosis is the result of haemolysis or recent blood loss, the blood smear shows polychromasia, which results from an increased reticulocyte count.

\section{Microcytic Anaemia}

The blood smear is generally less important in the differential diagnosis of the microcytic than the macrocytic anaemias. Red cell indices and serum ferritin levels, sometimes supplemented by markers of inflammation that are interpreted in the context of clinical features, permit the diagnosis of the majority of cases. However, it is important to note that the presence of Pappenheimer bodies and red cell dimorphism in the sideroblastic anaemias and of basophilic stippling in cases of lead poisoning.

\section{Thrombocytopenia}

A blood smear should always be examined for patients with thrombocytopenia, both to confirm the thrombocytopenia and to look for the underlying cause.

\section{Leucopenia/ Leukaemia/ Bone Marrow Failure}

Blood smears must always be examined when there is unexplained leukocytosis, lymphocytosis or monocytosis. Low rather than high counts likewise are an indication for a smear, since they may be indicative of aplastic anaemia, acute leukaemia, hairy-cell leukaemia or infiltration of nonhaematopoietic malignant cells into the bone marrow. The role of the blood smear in the diagnosis of leukaemia and lymphoma is to suggest a likely diagnosis or range of diagnoses to indicate which additional tests should be performed, and to provide a morphologic context without which immunophenotyping and other sophisticated investigations cannot be interpreted. For two conditions, Burkitt's lymphoma and acute promyelocytic leukaemia a blood smear is of particular importance, because it facilitates rapid diagnosis and specific treatment.

Examination of a peripheral blood smear for morphologic abnormalities of RBCs (and for leukocytes and platelets as well) should be part of any evaluation of anaemia. Anisocytosis indicates excessive numbers of RBCs with varying sizes. Poikilocytosis denotes variation in shape and contour of RBCs.

\section{Objectives}

1. To study the clinical profile of elderly patients with anaemia.

2. To study the haematological characteristics to know the patterns of anaemia in elderly.

\section{MATERIALS AND METHODS}

\section{Type of Study}

Descriptive study.

\section{Study Period}

12 months (May 2015 - May 2016).

\author{
Study Setting \\ Department of Pathology, Government Medical College, \\ Kottayam.
}

\section{Sample Size}

350. (Sample size, $\mathrm{N}=4 \mathrm{pq} / \mathrm{d} 2$ ).

$\mathrm{p}=$ prevalence $/$ proportion in previous study, $\mathrm{q}=100-\mathrm{p}, \mathrm{d}=$ allowable error- $5 \%$ ).

\section{Inclusion Criteria}

Patients aged above 65 years whose blood reports show $<13$ $\mathrm{g} \mathrm{Hb} / \mathrm{dL}$ among men and $<12 \mathrm{~g} \mathrm{Hb} / \mathrm{dL}$ among females.

\section{Exclusion Criteria}

Cases without proper data.

\section{Study Procedure}

350 Elderly patients (age $>65$ ) with blood reports showing $\mathrm{Hb}<13 \mathrm{~g} / \mathrm{dL}$ among men and $<12 \mathrm{~g} / \mathrm{dL}$ among women who approached the Department of Medicine at Government Medical College, Kottayam during the study period were evaluated clinically and their haematological characteristics were matched to the closest aetiology.

\section{Data Management and Analysis}

The data was entered in Microsoft Excel and further statistical analysis was done using available Institutional Software.

\section{RESULTS}

The present study was conducted on 350 elderly anaemic patients of Government Medical College, Kottayam. 


\section{Age and Gender Distribution}

The age group of patients ranged from 65 to 94 years. Maximum number of cases fell in the age group between 65 75 years. Of these males accounted for 103 (45\%) and females 128 (55\%) in this age group.

\section{Gender Distribution of Cases}

Of 350 elderly anaemic patients analysed during the study period, 165 (47\%) patients were males and 185 (53\%) were females.

\section{History}

\section{Socioeconomic Status}

Among the 350 patients, 194 (56\%) were below poverty line and 156 (44\%) were above poverty line. In both the socioeconomic groups, grade I (mild) anaemia was the most prevalent type.

\section{Food Habits}

Out of the 350, 322 (92\%) patients consumed a mixed diet consisting of cereals, vegetables, pulses, poultry, fish, milk and milk products, only $28(8 \%)$ strict vegetarians were present.

\begin{tabular}{|c|c|c|c|c|}
\hline Factor & Variable & Frequency & $\begin{array}{c}\text { Mean } \\
\text { Haemoglobin }\end{array}$ & P value \\
\hline \multirow{2}{*}{ Diet } & Vegetarian & 26 & $10.24 \pm 1.90$ & \multirow{2}{*}{0.362} \\
\cline { 2 - 4 } & Mixed & 322 & $9.80 \pm 2.17$ & \\
\hline $\begin{array}{c}\text { Socio- } \\
\text { economic } \\
\text { Status }\end{array}$ & APL & 156 & $9.77 \pm 2.07$ & \multirow{2}{*}{0.575} \\
\cline { 2 - 4 } & BPL & 194 & $9.90 \pm 2.22$ & \\
\hline
\end{tabular}

\section{Table 1. Showing Association between Food Habits and}

Socio-Economic Status with Mean Haemoglobin Value

The difference between the mean haemoglobin based on food habits $(p=0.362)$ and socio-economic status $(p=0.575)$ was not statistically significant.

\section{Addictions}

Among females, only 3 smokers and 10 pan chewers were present.

\section{Anaemia in Chronic Disease}

Among the study population, 281 patients were suffering from either single or multiple chronic disease such as diabetes, hypertension, coronary artery disease, chronic kidney disease, COPD and their mean haemoglobin was found to be $9.762 \pm 1.92$.

\section{Presenting Complaints}

$332(95 \%)$ cases had complaints of easy fatigability, 305 (87\%) had dyspnoea, 223 (64\%) had dyspepsia, 75 (22\%) had giddiness and loss of weight was found in 67 (20\%) of patients. Patients also presented with complaints of fever, bone pain and bleeding manifestations at the rate of $9 \%, 7 \%$ and $6 \%$ respectively.

\section{General Examination Findings}

Pallor was present in 178 (94.2\%) of patients with mild (Grade 1) anaemia and in all patients with moderate (Grade 2) and severe (Grade 3) anaemia; 231 (66\%) patients had other general examination findings (oedema, clubbing and lymphadenopathy) in varying proportions.

\section{Systemic Examination Findings}

$45(13 \%)$ patients had central nervous system findings (dementia, confusion, hemiparesis, cranial nerve palsy, gait abnormalities, numbness and tingling sensations); 29 (8\%) patients had cardiovascular system findings such as (rapid pulse rate, muffled heart sounds and ejection systolic murmur). 52 (15\%) patients had respiratory system findings like dyspnoea on exertion, crepitations and rhonchi; 70 (20\%) patients had gastrointestinal system findings (aphthous ulcers, cheilitis, dental caries, upper abdominal tenderness, hepatosplenomegaly).

The values of haemoglobin ranged from 2.6 to 11.9 in females and 3.2 to 12.9 in males with a mean of $9.8+/-2.2 \mathrm{~g}$ $\mathrm{Hb} / \mathrm{dL}$. Majority of the patients were categorised as WHO Grade 1 (mild) anaemia.

\section{Laboratory Evaluation}

\begin{tabular}{|c|c|c|c|}
\hline Factor & Variable & $\begin{array}{c}\text { Mean Haemoglobin } \\
\text { Value }\end{array}$ & P-value \\
\hline \multirow{2}{*}{ Gender } & Male & $10.4 \pm 2.0 \mathrm{gm} / \mathrm{dL}$ & \multirow{2}{*}{$<0.001$} \\
\cline { 2 - 3 } & Female & $9.2 \pm 2.1 \mathrm{gm} / \mathrm{dL}$ & \\
\hline \multicolumn{2}{|c|}{ Table 2. Showing Mean Haemoglobin Value of Study } \\
Population based on Gender \\
\hline
\end{tabular}

Among males mean $\mathrm{Hb}$ was $10.4 \pm 2.0 \mathrm{gm} / \mathrm{dL}$, while among females it was $9.2 \pm 2.1 \mathrm{gm} / \mathrm{dL}$. This difference was found to be statistically significant ' $t$ ' value (5.578) at $\mathrm{p}<0.001$.

\section{Peripheral Smear Findings}

\begin{tabular}{|c|c|c|c|c|}
\hline $\begin{array}{c}\text { Haemato- } \\
\text { logical } \\
\text { Parameters }\end{array}$ & $\begin{array}{c}\text { Normocytic } \\
\text { Normo } \\
\text { chromic } \\
\text { Anaemia }\end{array}$ & $\begin{array}{c}\text { Microcytic } \\
\text { Hypochromic } \\
\text { Anaemia }\end{array}$ & $\begin{array}{c}\text { Macro- } \\
\text { cytic } \\
\text { Anaemia }\end{array}$ & $\begin{array}{c}\text { Dimorphic } \\
\text { Anaemia }\end{array}$ \\
\hline $\mathrm{Hb}$ (g/ dL) & $10.2 \pm 1.9$ & $8.1 \pm 2.9$ & $8.9 \pm 1.9$ & $8.5 \pm 1.0$ \\
\hline $\mathrm{HCT}$ & $31.3 \pm 5.7$ & $25.5 \pm 8.6$ & $28.0 \pm 5.8$ & $26.2 \pm 3.3$ \\
\hline $\mathrm{MCV}(\mathrm{fL})$ & $85.7 \pm 5.0$ & $74.4 \pm 5.5$ & $\begin{array}{c}92.6 \pm \\
11.7\end{array}$ & $85.7 \pm 3.1$ \\
\hline $\mathrm{MCH}(\mathrm{pg})$ & $28.1 \pm 2.1$ & $23.2 \pm 3.4$ & $30.7 \pm 4.5$ & $27.7 \pm 1.8$ \\
\hline $\mathrm{MCHC}(\%)$ & $32.8 \pm 2.0$ & $30.8 \pm 2.6$ & $33.0 \pm 1.0$ & $33.9 \pm 5.2$ \\
\hline RDW (\%) & $15.1 \pm 2.7$ & $17.6 \pm 3.9$ & $\begin{array}{c}15.6 \pm \\
2.51\end{array}$ & $18.4 \pm 1.55$ \\
\hline
\end{tabular}

Table 3. Showing Haematological Parameters in Various Patterns of Anaemia

Out of 350 patients, majority 79\% (279) had normocytic normochromic blood picture. $43(12 \%)$ had microcytic hypochromic blood picture, 15 (4\%) had macrocytic blood picture and 13 (4\%) showed dimorphic blood picture. Some of the smears showed an increase in Rouleaux formation. One case of liver disease showed acanthocytes. One case of haemolytic uraemic syndrome showed evidence of haemolysis.

\begin{tabular}{|c|c|c|}
\hline Peripheral Smear RBC Morphology & Females & Males \\
\hline Normocytic normochromic pattern & $77.8 \%$ & $81.8 \%$ \\
\hline Microcytic hypochromic pattern & $16.8 \%$ & $12.7 \%$ \\
\hline Macrocytic pattern & $10.6 \%$ & $3.0 \%$ \\
\hline Dimorphic pattern & $1.3 \%$ & $2.4 \%$ \\
\hline \multicolumn{3}{|c|}{$\begin{array}{c}\text { Table 4. Showing Gender Wise Distribution of Study } \\
\text { Population based on the Morphological Pattern of Red } \\
\text { Blood Cells }\end{array}$} \\
\hline
\end{tabular}


WBC morphological changes such as hypersegmented neutrophils, toxic granules and Dohle bodies were seen in a few smears. Two cases of chronic lymphocytic leukaemia were diagnosed. Smears with thrombocytopenia, thrombocytosis and few with giant platelets were also observed.

Among the patients with underlying single/ multiple chronic diseases, the most common pattern was normocytic normochromic anaemia.

\section{Other Investigations}

Among the 350 patients 259 patients had done erythrocyte sedimentation rate, 205 patients had done renal function tests, 207 patients did random blood sugar levels, 118 did stool occult blood and all patients underwent urine routine examination. Bone marrow examination was done only on 26 patients, among them 20 showed erythroid hyperplasia, 4 showed megaloblastic maturation, one showed dysplastic features and 2 of them showed plasmacytosis which was confirmed as plasma cell myeloma by further biochemical investigations.

\begin{tabular}{|c|c|c|c|c|}
\hline \multirow{2}{*}{ Factor } & Variable & $\begin{array}{c}\text { Grade I } \\
\text { Anaemia }\end{array}$ & $\begin{array}{c}\text { Grade II } \\
\text { Anaemia }\end{array}$ & $\begin{array}{c}\text { Grade III } \\
\text { Anaemia }\end{array}$ \\
\hline $\begin{array}{c}\text { Renal function } \\
\text { test }\end{array}$ & Normal & 110 & 63 & 10 \\
\cline { 2 - 5 } $\begin{array}{c}\text { Random blood } \\
\text { sugar }\end{array}$ & Normal & 14 & 5 & 3 \\
\cline { 2 - 5 } $\begin{array}{c}\text { Urine routine } \\
\text { examination }\end{array}$ & Rlevated & 21 & 4 & 1 \\
\cline { 2 - 5 } & RBC present & 188 & 136 & 24 \\
\hline $\begin{array}{c}\text { Stool occult } \\
\text { blood }\end{array}$ & Negative & 61 & 40 & 7 \\
\cline { 2 - 5 } & Positive & 6 & 4 & 0 \\
\hline $\begin{array}{c}\text { Erythrocyte } \\
\text { sedimentation } \\
\text { rate }\end{array}$ & Normal & 100 & 89 & 20 \\
\cline { 2 - 5 } & Elevated & 24 & 15 & 11 \\
\hline $\begin{array}{c}\text { Table 5. Showing association between Renal Function } \\
\text { Test, Random Blood Sugar, Urine Routine Examination, } \\
\text { Stool Occult Blood, Erythrocyte Sedimentation }\end{array}$ \\
Rate with Grades of Anaemia \\
\hline
\end{tabular}

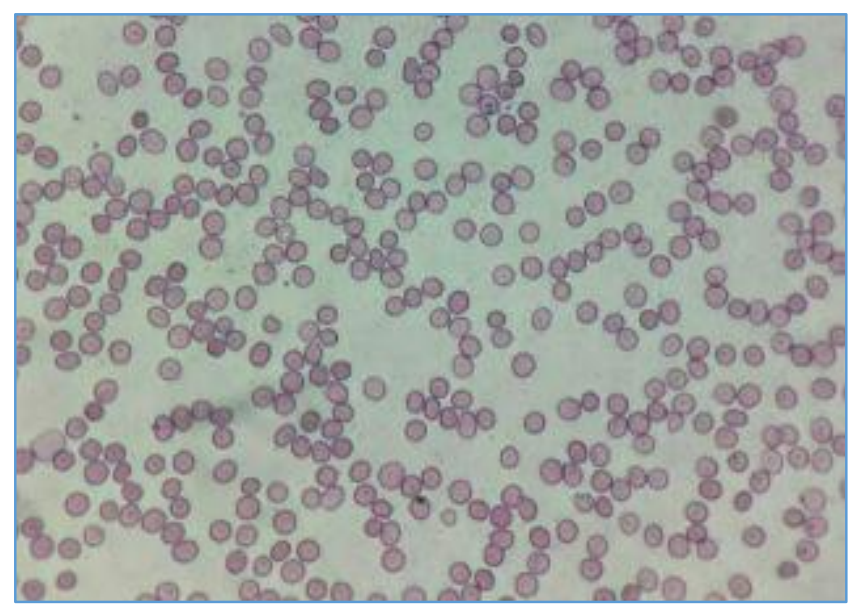

Peripheral Smear 40x Normocytic Normochromic Blood Picture

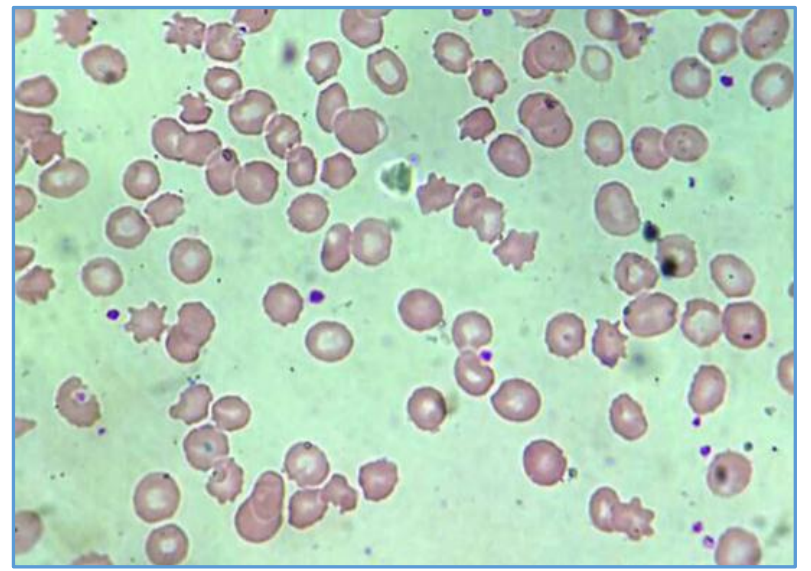

Peripheral Smear (100x) showing Acanthocytes in a Case of Liver Disease

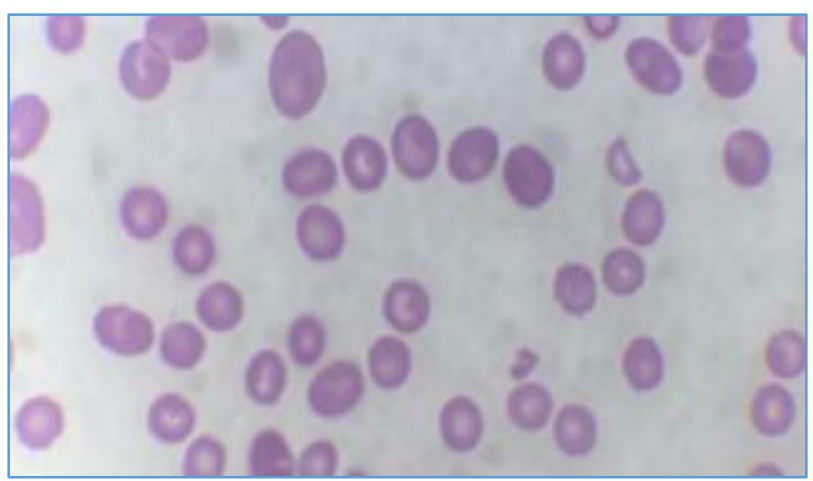

Peripheral Smear (100x) of Macrocytic Anaemia

\section{DISCUSSION}

In the present study, the WHO criteria was used for defining anaemia. Most of the Indian studies have used the same criteria and the trend of lower mean $\mathrm{Hb}$ value among female patients was seen. Among males mean $\mathrm{Hb}$ was $10.51 \pm 2.03$ $\mathrm{g} / \mathrm{dL}$, while among females it was $9.26 \pm 2.13 \mathrm{~g} / \mathrm{dL}$. This difference was found to be statistically significant ' $t$ ' value (5.578) at $\mathrm{p}<0.001$.

In the present study the cut-off age was taken as 65 years to define elderly, and the relative proportion among the age groups 65 - 75 years, 75 - 85 years and above 85 years were found to be $65.7 \%, 31.4 \%$ and $2.9 \%$ respectively. The relative proportion in each age group was in concordance with studies by Saurabh Srivastava.

In the present study $64 \%$ of women consumed a mixed diet consisting of poultry, fish, meat, milk and milk products, whereas studies show that in India only $28 \%$ of women consume meat, fish or eggs on a weekly basis.

In the present study, the most common clinical presentation was easy fatigability (94.9\%) followed by dyspepsia $(63.7 \%)$ breathlessness on exertion (13\%) and giddiness in $21.4 \%$. Palpitation and anorexia was seen in $20 \%$ of geriatric patients. Patients also presented with complaints of fever, bone pain and bleeding at the rate of $9 \%, 7 \%$ and $6 \%$ respectively. Similar observations were made by Prakash KG et al, Anuradha Deuri et al and Bhasin A et al in their studies in South India. In the study by Anuradha Deuri et al the most common clinical presentation were easy fatigability (91\%), followed by breathlessness on exertion (72\%) and difficulty on walking (56\%). Palpitation and anorexia was seen in $48 \%$ 
of geriatric patients. In the study conducted in South India by Prakash KG et al, the most common presentation was easy fatigability $44(88 \%)$ followed by dyspnoea $35(70 \%)$ and giddiness $30(60 \%)$. The rare presentations were bleeding per rectum $3(6 \%)$, difficulty in walking $2(4 \%)$ and haematemesis $1(2 \%) .3,4$

In the present study, 45 (13\%) patients had central nervous system findings (dementia, confusion, hemiparesis, cranial nerve palsy, gait abnormalities, numbness and tingling sensations). 29 (8\%) patients had cardiovascular system findings such as (rapid pulse rate, muffled heart sounds, ejection systolic murmur). 52 (15\%) patients had respiratory system findings like dyspnoea on exertion, crepitations and rhonchi. 70 (20\%) patients had gastrointestinal system findings (aphthous ulcers, cheilitis, dental caries, upper abdominal tenderness, hepatosplenomegaly).

\begin{tabular}{|c|c|c|}
\hline Systemic Examination & $\begin{array}{c}\text { Tabea Geisel } \\
\text { et al (n= 405) }\end{array}$ & $\begin{array}{c}\text { Present Study } \\
\text { (n= 350) }\end{array}$ \\
\hline Central nervous system & $40.63 \%$ & $13 \%$ \\
\hline Cardiovascular system & $57.4 \%$ & $8 \%$ \\
\hline Respiratory system & $50 \%$ & $15 \%$ \\
\hline Gastrointestinal system & $86 \%$ & $20 \%$ \\
\hline Table 6. Showing Comparison of Findings on Systemic \\
Examination $^{3}$
\end{tabular}

On comparison with the study conducted by Tabea Geisel et al, the contrast shown could be attributed to the difference in study population, i.e. those of Tabea Geisel et al were purely hospitalised patients, while that of the present study consisted of both hospitalised and outpatient population.

In the present study, majority (54\%) of the patients had Grade 1 (mild) anaemia. It was in concordance with another hospital-based study conducted by Tabea Geisel et al. While in the study conducted by Prakash KG et al, it was found that Grade 1 category was comprising of only $18 \%$ of their study population and in the study conducted by Anuradha Deuri et al majority $(62 \%)$ belonged to the category of Grade 2 (moderate) anaemia of the WHO grading system. . $^{4} 3$

\begin{tabular}{|c|c|c|c|c|}
\hline $\begin{array}{c}\text { Grade } \\
\text { of } \\
\text { Anaemia }\end{array}$ & $\begin{array}{c}\text { KG } \\
\text { Prakash } \\
\text { et al } \\
\text { (n= 50) }\end{array}$ & $\begin{array}{c}\text { Anuradha } \\
\text { Deuri } \\
\text { et al } \\
\text { (n=100) }\end{array}$ & $\begin{array}{c}\text { Tabea } \\
\text { Geisel } \\
\text { et al } \\
(\mathbf{n = 4 0 5 )}\end{array}$ & $\begin{array}{c}\text { Present } \\
\text { Study } \\
\text { (n= 350) }\end{array}$ \\
\hline $\begin{array}{c}\text { Severe } \\
\text { (Grade 3) }\end{array}$ & $42 \%$ & $17 \%$ & $1.5 \%$ & $7 \%$ \\
\hline $\begin{array}{c}\text { Moderate } \\
\text { (Grade 2) }\end{array}$ & $40 \%$ & $62 \%$ & $13.5 \%$ & $39 \%$ \\
\hline $\begin{array}{c}\text { Mild } \\
\text { (Grade 1) }\end{array}$ & $18 \%$ & $21 \%$ & $85.1 \%$ & $54 \%$ \\
\hline
\end{tabular}

Table 7. Showing Comparison of Grade of Anaemia ${ }^{4,5,3}$

The most prevalent peripheral smear pattern of anaemia was normocytic normochromic anaemia in all the studies shown below.

\begin{tabular}{|c|c|c|c|c|c|c|}
\hline $\begin{array}{l}\text { Peripheral Smear } \\
\text { Morphology }\end{array}$ & $\begin{array}{c}\text { Bhasin and } \\
\text { Rao } \\
(n=100)\end{array}$ & $\begin{array}{c}\text { Vanamala Alwar } \\
\text { et al } \\
(n=236)\end{array}$ & $\begin{array}{c}\text { KG Prakash } \\
\text { et al } \\
(n=50)\end{array}$ & $\begin{array}{c}\text { Anuradha Deuri } \\
\text { et al }(n=100)\end{array}$ & $\begin{array}{c}\text { Saurabh } \\
\text { Srivastava } \\
(n=654)\end{array}$ & $\begin{array}{l}\text { Present Study } \\
\quad(n=350)\end{array}$ \\
\hline $\begin{array}{c}\text { Normocytic } \\
\text { normochromic pattern }\end{array}$ & $62 \%$ & $66.1 \%$ & $52 \%$ & $58 \%$ & $78.05 \%$ & $79 \%$ \\
\hline $\begin{array}{c}\text { Microcytic hypochromic } \\
\text { pattern }\end{array}$ & $30 \%$ & $25.84 \%$ & $32 \%$ & $38 \%$ & $11.6 \%$ & $12 \%$ \\
\hline Macrocytic & $6 \%$ & $7.22 \%$ & $16 \%$ & $4 \%$ & $6.02 \%$ & $4 \%$ \\
\hline Dimorphic & $0 \%$ & $0.84 \%$ & $0 \%$ & $0 \%$ & $4.24 \%$ & $4 \%$ \\
\hline
\end{tabular}

\begin{tabular}{|c|c|c|c|}
\hline $\begin{array}{c}\text { Peripheral Smear } \\
\text { Morphology in } \\
\text { Women }\end{array}$ & $\begin{array}{c}\text { Ania et al } \\
(\mathbf{n = 6 1 8})\end{array}$ & $\begin{array}{c}\text { Saurabh } \\
\text { Srivastava } \\
\text { (n= 654) }\end{array}$ & $\begin{array}{c}\text { Present } \\
\text { Study } \\
(\mathbf{n = 3 5 0})\end{array}$ \\
\hline $\begin{array}{c}\text { Normocytic } \\
\text { normochromic pattern }\end{array}$ & $80 \%$ & $79.2 \%$ & $77.8 \%$ \\
\hline $\begin{array}{c}\text { Microcytic } \\
\text { hypochromic pattern }\end{array}$ & $16 \%$ & $14.9 \%$ & $11.9 \%$ \\
\hline Macrocytic & $4 \%$ & $4 \%$ & $5.4 \%$ \\
\hline Dimorphic & $0 \%$ & $1.9 \%$ & $4.9 \%$ \\
\hline Table 9. Showing Comparison of RBC Morphology in \\
Females ${ }^{6,8}$ \\
\hline
\end{tabular}

\begin{tabular}{|c|c|c|c|}
\hline $\begin{array}{l}\text { Peripheral Smear } \\
\text { Morphology in Men }\end{array}$ & $\begin{array}{c}\text { Ania et al } \\
(n=618)\end{array}$ & $\begin{array}{c}\text { Saurabh } \\
\text { Srivastava } \\
(n=654)\end{array}$ & $\begin{array}{c}\text { Present } \\
\text { Study } \\
(n=350)\end{array}$ \\
\hline $\begin{array}{c}\text { Normocytic } \\
\text { normochromic pattern }\end{array}$ & $83 \%$ & $71.3 \%$ & $81.8 \%$ \\
\hline $\begin{array}{c}\text { Microcytic } \\
\text { hypochromic pattern }\end{array}$ & $14 \%$ & $16.8 \%$ & $12.7 \%$ \\
\hline Macrocytic & $3 \%$ & $10.6 \%$ & $3 \%$ \\
\hline Dimorphic & $0 \%$ & $1.3 \%$ & $2.4 \%$ \\
\hline \multicolumn{4}{|c|}{$\begin{array}{l}\text { Table 10. Showing Comparison of RBC Morphology in } \\
\qquad \text { Males } 6,8^{6}\end{array}$} \\
\hline
\end{tabular}

\begin{abstract}
Anaemia of Chronic Disease and Normocytic Normochromic Anaemia

In the present study majority (82\%) of the patients who had chronic diseases like diabetes, hypertension, COPD, chronic renal disease, coronary artery disease had normocytic normochromic blood picture on peripheral smear examination. In the study conducted by Prakash KG et al, anaemia of chronic inflammation was also the most common cause of normocytic anaemia. $68.75 \%$ of patients with anaemia of chronic inflammation had normocytosis, while $31.25 \%$ had microcytosis. Anaemia of chronic inflammation contributed to $42.30 \%$ of anaemia with normocytosis and was the most common aetiology. Similar results were observed by Weiss et al. Anaemia of chronic Inflammation was the most common cause of anaemia in the elderly patients. ${ }^{4}$
\end{abstract}

\section{CONCLUSION}

The clinical profile of elderly anaemic patients revealed that easy fatigability was the presenting symptom of most of the patients. The patients had varied physical examination findings corresponding to their underlying disease. 


\section{Jemds.com}

Haematological profile showed that most of the patients had Grade 1 anaemia, normocytic normochromic blood picture on peripheral smear examination.

To conclude anaemia in elderly is a common serious problem of the era, which bears a major disease burden. Timely accurate diagnosis is essential for the appropriate management.

\section{ACKNOWLEDGEMENT}

I express my sincere thanks and gratitude to Dr. Sankar S, Head of Department, Department of Pathology. Govt. Medical College, Kottayam, and my guide Dr. Prabhalakshmi KK, Associate Professor, Department of Pathology for their passion and dedication.

\section{REFERENCES}

[1] Udristioiu A, Cojocaru M, Florescu C, et al. Screening tests for latent anemia in hospitalized adults over the age of 65. Lab Medicine 2010;41(5):288-91.

[2] Artz AS. Anemia in elderly persons. Medscape 2015.

\section{Original Research Article}

[3] Geisel T, Martin J, Schulze B, et al. An etiologic profile of anemia in 405 geriatric patients. Hindawi Publishing Corporation Article ID 932486, 2014;2014:7.

[4] Prakash KG, Devendrappa KR, Madhukumar MH, et al. Clinical profile of anemia in elderly: a cross sectional study from a tertiary care centre. Scholars Journal of Applied Medical Sciences 2015;3(3C):1266-70.

[5] Deuri A. Clinical and aetiological profile of anaemia in geriatric patients: a hospital based study in Assam, India. Sch J App Med Sci 2016;4(8B):2873-9.

[6] Shrivastava SR, Hippargi SB, Ambali AP, et al. Patterns of anemia in geriatric age group. JKIMSU 2013;2(1):77-81.

[7] Bhasin A, Rao MY. Characteristics of anemia in elderly: a hospital based study in south India. Indian J Hematol Blood Transfus 2011;27(1):26-32.

[8] Ania BJ, Suman VJ, Fairbanks VF, et al. Incidence of anemia in older people: an epidemiologic study in a well-defined population. J Am Geriatric Soc 1997;45(7):825-31. 